\title{
Development of nursing management competencies: guidelines for continuous education services*
}

\author{
Desenvolvimento de competências gerenciais do enfermeiro: \\ diretriz para serviços de educação permanente \\ Desarrollo de competencias de gestión del enfermero: directriz \\ para servicios de educación permanente
}

Priscila Meyenberg Cunha Sade ${ }^{1}$, Aida Maris Peres ${ }^{2}$

\footnotetext{
* Extracted from the dissertation

"Desenvolvimento de competências gerenciais dos enfermeiros pelos serviços de educação permanente," Programa de Pós-Graduação em Enfermagem, Universidade Federal do Paraná, 2013.

${ }^{1}$ Universidade Federal do Paraná, Programa de Pós-Graduação em Enfermagem, Curitiba, PR, Brazil.

${ }^{2}$ Universidade Federal do Paraná, Departamento de Enfermagem, Curitiba, PR, Brazil.
}

\section{ABSTRACT}

Objective: Developing continuing education guidelines for the development of nursing management competencies along with the members of the Center of Nursing Continuing Education of Parana. Method: A qualitative research outlined by the action research method, with a sample consisting of 16 nurses. Data collection was carried out in three stages and data were analyzed according to the thematic analysis technique. Results: It was possible to discuss the demands and difficulties in developing nursing management competencies in hospital organizations and to collectively design a guideline. Conclusion: The action research contributed to the production of knowledge, confirming the need and the importance of changing the educational processes and evaluations, based on methodologies and instruments for professional development in accordance with human resource policies and contemporary organizational policies.

\section{DESCRIPTORS}

Education, Nursing, Continuing; Professional Competence; Nursing, Supervisory; Nursing Administration Research. 


\section{INTRODUCTION}

Currently the demands of the working world have been increasingly requiring an entrepreneurial profile from professionals. In the health area, and in particular with regard to nurses, their training and their daily professional practice follow the same tendencies supported by the perspective of competencies-ability that one has to take initiatives (not just being limited to predetermined activities), understand and master new situations at work, take responsibility and be recognized for their actions ${ }^{(1)}$.

The development of competencies during academic training does not guarantee the renewal of the practice. Perfecting these practices should be a personal commitment of nurses and employing organizations through forming a network of continuous knowledge. This possibility enables management competencies to be demystified as an ability and a natural talent, since they can be acquired resulting from the combination of capabilities, organized practices and knowledge that can be built from academic training and more permanently in professional Nursing practice ${ }^{(2-3)}$.

In this perspective, considerations arise that go against the National Continuing Education Policy, which advocates that the educational process is as much of a responsibility of the institutional sphere as the individual sphere. Continuous education can be viable if it is focused on continuous updating that seeks to innovate and meet the needs of the working world, as long as the institution along with professionals are committed to facilitating the planning, participating and also developing education actions $^{(3)}$.

Some studies have indicated the need for the mobilization of nursing management competencies at an academic education level, and that they relate to the demands of the working world(4-6). However, the debate is still scarce with regard to investigations on continuing education for nursing management practice in the employment/work context ${ }^{(2-3)}$.

Added to this, the Center for Nurses Continuing Education of Parana (NEEP/PR), an independent non-profit nursing organization which evaluates the continuing education of the Health services in the state of Paraná, has highlighted their concerns about the lack of thematic approach of management competencies in continuing education for nurses.

The starting point for this study took place during the presentation of these concerns to NEEP/PR, when other members of this organization voiced their dissatisfaction against the management nursing education at the academic level and the way training activities were being carried out in hospital organizations, as effective changes in nursing management practices were not being observed. Therefore, it was considered important to identify the demands and establish strategies which would culminate in this study aimed at designing a continuing education guideline for the development of nursing management competencies along with members of NEEP/PR.

\section{METHOD}

This is a qualitative research using the action research method $^{(7)}$ carried out at NEEP/PR. The study sample consisted of 16 nurses who were part of this organization in 2013.

The inclusion criteria adopted were: nurses being permanent members of NEEP/PR with regular participation in monthly meetings (with no more than three absences in a period of 12 months), accepting participation in the study by signing the Informed Consent Form (IC) and being registered to a continuing education service of a hospital organization. The following were applied as exclusion criteria: nurses who declined to participate in the study, nursings members of NEEP/PR who did not regularly participate in meetings (with more than three absences in a period of 12 months) and other professionals invited to attend meetings as guests.

Data collection was carried out in three steps: Step 1: semi-structured interviews - between January/2012 and March/2013; Step 2: Discussion Seminar - March/2013; Step 3: Planning Seminars - between April/2013 and June/2013.

Semi-structured interviews included the characterization data of all participants and those related to the identification of demands, responses to meet these demands, problems, and suggestions for improving the development of management competencies of continuing education services within the reasoning of continuing education ${ }^{(7)}$. To ensure anonymity, the dialogues of the participants were transcribed and coded with a capital letter "E" and numbers determined by the order of the interviews, for example, E1, $\mathrm{E} 2, \mathrm{E} 3$, and so on.

The data obtained from the interviews were translated in the form of a qualitative study focused on registered units, numbered in units of significance, classified and aggregated into categories, concluding with the preparation of a synthesis report.

The summary report proposes the presentation of the results obtained to create a collective information effect or 'self-awareness' in the organization about its problems over a short period of time ${ }^{(7-8)}$. The report presentation to the participants aimed at giving feedback on the information which they generated, as well as providing a space for collective dialogue.

In the seminar discussion, participants met to consider the results and the overall situation portrayed by them during the interviews, and to determine two or three areas of priority activity in research and action ${ }^{(8)}$. This event was held in April 2013 and 12 nurses participated. In this seminar, we presented a model of planning, training and development $^{(9)}$ to support the guideline, in order to design an action plan for a Continuing Education program for the development of competencies.

Three planning seminars (A, B and C) were carried out in the months of May, June and July 2013, with the participation of six, nine and nine participants, respectively. The seminars were 1 hour and 8 minutes long on average and provided a critical and reflective discussion of the issues listed by the group as the most relevant for the 
development of continuing education guidelines for the development of nursing management competencies in hospital organizations ${ }^{(9)}$.

Data from the semi-structured interviews and discussion seminars and planning were analyzed according to the content analysis technique, in the thematic approach ${ }^{(10)}$. The organization of the content analysis had three stages: preanalysis, material exploration and treatment of results.

We emphasize that this study is in accordance with the guidelines and ethical standards of research involving humans. The project was submitted to the Committee of Ethics in Research for the Health Sciences Sector of the Universidade Federal do Paraná (CEP SCS/UFPR) and approved under protocol number CAAE: 06903612.8.0000.0102.

\section{RESULTS}

All research participants were nurses from hospitals. The age range was 25-50 years, with a mean age of 34 years. Regarding the highest degree, there was a prevalence of specialization. The longest training time was 28 years and the shortest was 1.5 years. The actuation time in ongoing or Continuous Education ranged between 4 and 96 months. There was a predominance of assistance in professional practice of the participants focused on education, before being assigned to the current activity. It is noteworthy to highlight that two nurses, one a nursing manager and another nurse responsible for Competency in Hospital Infection Control (CHIC), also had Continuous Education coordinating activities as part of their function.

The themes that emerged from the empirical categories of this study were: management competencies that require development; difficulties encountered in the development of management competencies; and collective construction of guidelines as a strategy for development of nursing competencies.

\section{Management Competencies that ReQUiRe DeVelopment}

Participants cited leadership and continuing education as management competencies that require improvement in the context of their hospital organizations, which are demands of continuing education service under their responsibility:

(...) team leadership, this is the most difficult. Because nowadays in the university (...) they have no practical experience of coordinating a team (...) (E2).

(...) for me the biggest difficulty is for nurses to understand that they are responsible for their team's continuing education, (...) the technicians (really) follow the leader. (E3).

\section{DIFFICULTIES IN THE DEVELOPMENT OF NURSINC MANAGEMENT COMPETENCIES IN THE HOSPITAL ORGANIZATIONS}

The difficulties listed by the research participants for the development of nursing management competencies in hospital organizations were: dissociation between teaching and practice; the lack of commitment of nursing professionals; the lack of human, physical and financial resources; and lack of hierarchical support.

The dissociation between teaching and practice became clear from participants reporting that newly graduated nurses or those with little experience did not come prepared to play their managerial functions, generating training and development demands for continuing education services:

\section{(... ) they come unprepared (...) Sometimes they even understand the theory, but because of the short training time, or even unprepared teachers (...) they are now in need of this fellowship, and need to be following others. They cannot perform their most important role, which is to follow the technician who is coming to their team and those that are already on the team (E2).}

And the new nurses who arrive [negative facial expression], the younger they are, the more unprepared they are (E3).

Research participants also mentioned the Lack of commitment of nursing professionals in participating in the structuring and planning of training promoted by the continuing education service:

\section{Adherence is very complicated, in the two months that I've been working with the teams, the nurs- es do not participate (E13).}

I invited the nurses from the neonatal and the pediatric units to structure a training session (...). I sent the first e-mail in March, and to this date [May] I have not received an answer. We have a lot of difficulty with training adherence of supervisors and managers, which really complicates the process (E14).

Other difficulties cited by the participants correspond to the Lack of human, physical and financial resources for the development of nursing management competencies:

\section{(...) We lack human, and physical resources, a spe- cific budget for education, financial incentives for the professional seeking to improve in their area (...) (E5).}

The lack of hierarchical support was also raised by some participants, considered of great importance in the development process of nursing management competencies:

The biggest problem we face is the vertical hierarchy. In the sense that we are pointing to the solution, but we do not have support from senior managements. This represents the lack of support (...) (E4).

Ifeel that when you have support of the coordination and management, you are half way there. Because I do not feel like I have that support, it seems that I have to start from scratch (E8). 
Collective CONSTRUCTION OF GUIDELINES AS A STRATEGY FOR THE DEVELOPMENT OF NURSING COMPETENCIES

The collective construction of the guidelines took place in Planning Seminars A and B. In Planning Seminar A, participants chose the following as main points: partnerships with a human resources/psychologist service or outsourced companies; the need for a continuous competencies' development project; and involvement of directors and management:

\section{A project that would last all year long, so they would get involved and develop competencies. Something that would be permanent (E8). \\ When you can have this partnership [between $H R$, psychologist or outsourced companies], it is very productive. And I think it should involve more people; involve the hospital board, the HR management (E8). \\ (...) associating other managers to work in a mul- tidisciplinary way, to develop better work (E1).}

It is worth mentioning that in Planning Seminar A, the title, objective and the outline of the steps of the guideline structure were defined, considering description, action and accomplishment time of its dimensions.

Based on the data from the interviews from the Discussion Seminars and Planning Seminar A, a draft guideline was submitted in Planning Seminar B in order to confirm the relevance of its content, and also to have adjustments, revisions and improvements made by the group. These were related to setting defined management competencies, using active teaching methodologies and specific tools for evaluating the program, and as a recommendation, to map the nursing competencies.

\section{We would first need to agree on a definition of these competencies (E6).}

Participative teaching methodology, present the content, and based on these contents, work with role-playing, with workshops, scientific meetings, discussion groups (E3).

Allow a moment of reflection for the group, with organizing modules involving similar groups (E8).

Align it [the evaluation] with indicators, using reaction evaluation and critical analysis, in order to be able to show the importance and impact of education (E16).

Finally, in the Planning Seminar C, the guidelines which were validated and approved by the group are configured in a Continuing Education program that follows these steps: situation analysis, design, implementation, evaluative purpose and report (Figure 1). The purpose of the guidelines were defined as: to promote continuous improvement, based on meaningful learning in the development of nursing management competencies, in response to the needs of internal and external environments of organizations and the demands of these professionals, from the perspective of the Continuing Education Policy.

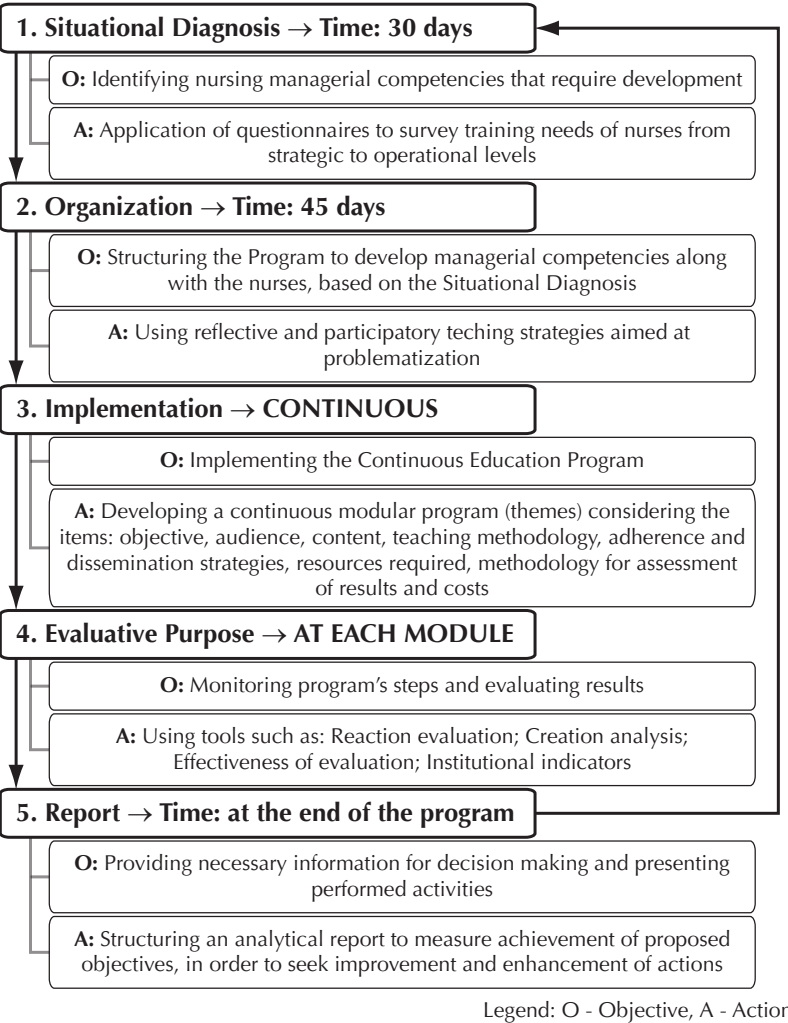

Figure 1 - Diagram summarizing the guidelines for the development of nursing management competencies - Curitiba, PR, Brazil, 2013.

\section{DISCUSSION}

From the participants' dialogues it becomes clear that leadership development is the most required among the nursing management competencies in the work process of hospital organizations ${ }^{(11-12)}$. To meet this demand, the continuous education service should use the strategy of Continuing Education, which provides space for thinking and creating a favorable scenario for professional development in the workplace, considered complex and absorbing for many of the nursing professionals.

In the context of hospital organizations in the studied scenario, the urgency in adopting leadership development programs and continuous education projects is evident, in order to prepare nurses to play the leadership role, and based on the establishment of an efficient communication process that stimulates autonomy, co-responsibility and the appreciation for leaders and collaborators ${ }^{(13)}$.

Research participants also mentioned the importance of the nurse recognizing the continuing education for selfimprovement, their team improvement and improvement in the management of the unit under their responsibility. From the perspective of the World Health Organization Human Resources Development Program, continuing education is understood as education that is developed in the workspace, by the work and for the work. It is a form of education in the employment context, in order to respond to the changes 
occurring in the working world and which should be considered as a strategy for the qualification of the worker ${ }^{(2-3,14-15)}$.

Some participants pointed out the difficulty of nurses in their organizations to understand that in addition to being able to learn how to learn, they have the duty and commitment to educating the professionals under their responsibility. Above all, provide relevant training to their team so that its members learn new concepts, attitudes, solutions, and ideas, thereby modifying habits and behaviors and becoming more effective in what they $\mathrm{do}^{(16-17)}$.

However, it is known that due to the complexity of healthcare organizations, the nurse having only the intention to develop their team is not enough. This responsibility needs to be shared with institutional support. Based on this and according to the statements of the research participants, it is imperative that nurses discuss and rethink their role as educators, and that organizations assert their commitment to managerial development of their employees by investing in ongoing education as a resource which will boost the autonomy and personal, professional and organizational growth ${ }^{(15)}$.

The difficulties encountered by continuous education services in developing nursing management competencies were: the dissociation between teaching and practice; the lack of professional nursing commitment; the lack of human, physical and financial resources; and lack of hierarchical support.

Research participants reported that nurses arrive unprepared to act in their managerial function. Developing skills and general competencies identified by the National Curricular Guidelines (DCN) has been a major challenge for educational institutions due to the complexity of the labor market and due to prevalent pedagogical approaches in Nursing training being based on knowledge transmission, disregarding active teaching methodologies that enable an emancipatory education and transform reality, thus allowing the individual to answer the challenges of the contemporary world ${ }^{(3,18)}$.

With this, the debate between the labor market and academics remains; as pointed out by the research participants, it is centralized in the profile of professionals being trained, which often differs from the demands and expectations of hospital organizations.

In this sense, the development of competencies is justified as being an ongoing process fostered by the organization as a component of an evolving system of the labor market. It requires association between teaching and practice, as well as new professional profiles and management models that require the mobilization of continuous knowledge. It is necessary to mention that management competencies are absorbed throughout nursing training, guided by the context of reality and critical know-how centered on contextualized content of contemporaneity; and in the workplace, through experiential learning in work situations with a view toward continuous improvement $t^{(2-3)}$.

In the researched scenario, nurses have low participation in continuing education programs, which may be related to the multiple activities they perform, and therefore, time constraints, staff shortages and prior negative experiences with programs that followed continuing education $\operatorname{logic}{ }^{(14)}$. Therefore, nurses need to understand that in the context of hospital organizations, they (the nurses) constitute a human resource of continuous education, recognizing that their commitment to programs will guide the creation, dissemination and use of knowledge in order to achieve organizational goals.

The existence of a continuous education service in the hospital organization does not negate the need for nurses' participation in educational processes. This is due to the fact they maintain direct and continuous contact with the nursing staff, being able to more appropriately understand/ grasp the reality and to assess practical needs ${ }^{(19)}$.

To develop their activities, continuous education services require human, material, financial and adequate physical resources. When insufficient, they become limiting factors to the development of training and development programs ${ }^{(20)}$.

We emphasize that in this study, two nurses combined other activities in addition to coordinating continuous education. Often the failure of continuous education programs is due to coordinators working part-time, having other activities such as monitoring units, covering for missing personal, as well as vacation and sick leaves. As a result, these nurses do not have time, nor are able to exclusively devote themselves to the education activities. Therefore, the programs are poorly designed and inadequate ${ }^{(20)}$.

Regarding physical resources, as reported during the seminars, it is necessary that the physical structure is appropriate. When the continuous education sector has resources like equipped classrooms and simulation labs, it is easier to develop programs ${ }^{(20-22)}$.

With regard to financial resources, these depend on the institution's policy and its interest in investing in human capital. Nowadays, the great challenge for managers responsible for the continuing education sectors is achieving maximum positive results by performing training and developing programs using minimum financial resources ${ }^{(21)}$.

However, financial support invested in training alone and development of human resources is not enough to guarantee good performance of workers. Other factors that also affect the quality and excellence of continuing education programs must be taken into consideration, such as the motivation and preparation of the nursing staff, the organizational culture that recognizes and values the continuous education sector and the availability material resources ${ }^{(15,20)}$.

Some research participants who reported the lack of support from hierarchical superiors as a difficulty for the development of management competencies are tied to $\mathrm{Hu}-$ man Resource Management, to Quality Management or to the General Direction of hospital organizations. This type of structure (not linked to management / nursing department) hinders nursing to be free to decide on education programs to be developed.

Hierarchical support is critical for the success of education programs that actually generate expected results. To do so, these programs should be designed in accordance with objectives of the organization and in a participatory manner involving teachers and students, regardless of what the administrative structure of the continuous education service is ${ }^{(20)}$. 
Regarding visibility of the continuous education service work process, it can be said that the research participants have broadened their horizons to produce changes in their own management of their work process as they designed the guidelines. Their statements corroborate the reality of most hospital organizations in relation to the processes of quality certification. These go against the necessity of using indicators and/or instruments, that in addition to evaluating the continuous education service, will also provide effective measures of the continuous education impact on nursing work processes and the nursing staff ${ }^{(16,19)}$.

The participants positioned themselves towards the importance of coordinating, evaluating, documenting training and development programs, and therefore assuming and making their strategic placement in organizations visible through the adoption of participatory management. This results in easing the power relations and focuses on having individuals aware about their responsibility for self-improvement, for socializing knowledge and to learning new knowledge as the logic of Continuing Education ${ }^{(16)}$.

\section{CONCLUSION}

The results of this study highlight the management competencies of leadership and continuing education requiring development in hospital organizations, according to the studied scenario. These are mainly related to the sense of nurses being leaders of their teams and understanding the importance of getting involved and being responsible for their own education, in planning it, and positioning themselves as facilitators of educational activities proposed for themselves and their team.

We emphasize that the collective construction of the guidelines has led to a feeling of belonging by the group and the appreciation of NEEP/PR as an effective space for discussion and critical-reflection in building knowledge. Consequently, nurses are enabled to understand their strategic position in continuous education as educational programs coordinators and facilitators of the general strategy of organizational change.

Action research is an opportunity for reflection on the reality of the nursing management work process. It facilitated the mobilization of knowledge and expanded the vision of NEEP/PR members, thereby allowing the construction of a guideline consensus, contributing to the production of knowledge, and confirmed the need and importance of changes in the educational and evaluation processes to be based on methodologies and tools that enable the development of professionals according to human resource policies and current organizational policies.

As a limitation, it could be pointed out that the duration of the research did not allow for the application of the guidelines, being necessary for the production of theoretical and practical knowledge regarding the effective implementation of the continuous education program. Therefore, we propose a continuation of studies to apply and evaluate the impact of implemented development programs of management competencies with national and international health and education policies as criteria.

We conclude that it is possible to develop nursing management competencies along the logic of continuous education, however it is necessary to understand these competencies not only as acquired individual attributes and the construction of knowledge for nurses, but also contextualized based on the demands of the real situations of labor practice.

\section{RESUMO}

Objetivo: Construir uma diretriz de educação permanente para o desenvolvimento de competências gerenciais dos enfermeiros junto aos membros do Núcleo de Enfermeiros de Educação Permanente do Paraná. Método: Pesquisa com abordagem qualitativa, delineada pelo método da pesquisa-ação, composta por amostra de 16 enfermeiros. A coleta de dados ocorreu em três etapas e os dados analisados segundo a técnica de análise temática. Resultados: Foi possível discorrer sobre as demandas e as dificuldades para o desenvolvimento de competências gerenciais do enfermeiro nas organizações hospitalares e estruturar coletivamente uma diretriz. Conclusão: A pesquisaação contribuiu para a produção de conhecimentos, confirmando a necessidade e a importância de mudanças nos processos educativos e de avaliação fundamentados em metodologias e instrumentos que permitam o desenvolvimento de profissionais consoante às políticas de recursos humanos e organizacionais contemporâneas.

\section{DESCRITORES}

Educação Continuada em Enfermagem; Competência Profissional; Supervisão de Enfermagem; Pesquisa em Administração de Enfermagem.

\section{RESUMEN}

Objetivo: Construir una directriz de educación permanente para el desarrollo de competencias de gestión para los enfermeros junto con los miembros del Núcleo de Enfermeros de Educación Permanente de Paraná. Método: Investigación con abordaje cualitativo, diseñado por el método de investigación-acción compuesto de muestra de 16 enfermeros. La recolección de datos ocurrió en tres etapas y los datos fueron analizados según la técnica de análisis temático. Resultados: Fue posible discurrir sobre las demandas y las dificultades para el desarrollo de competencias de gestión del enfermero en las organizaciones hospitalarias y estructurar colectivamente una directriz. Conclusión: La investigación-acción contribuyó a la producción de conocimientos, confirmando la necesidad y la importancia de cambios en los procesos educativos y de evaluación fundados en metodologías e instrumentos que permitan el desarrollo de profesionales acorde con las políticas de recursos humanos y organizaciones contemporáneas.

\section{DESCRIPTORES}

Educación Continua en Enfermería; Competencia Profesional; Supervisión de Enfermería; Investigación en Administración de Enfermería. 


\section{REFERENCES}

1. Zarafian P. Objetivo competência: por uma nova lógica. São Paulo: Atlas; 2001.

2. Soto-Fuentes P, Reynaldos-Grandón K, Martínez-Santana D, Jerez-Yáñez O. Competencias para la enfermera/o en el ámbito de gestión y administración: desafíos actuales de la profesión. Aquichán [Internet]. 2014 [citado 2015 Jun. 15];14(1):79-99. Dispinible en: http://www. scielo.org.co/pdf/aqui/v14n1/v14n1a08.pdf

3. Miccas FL, Batista SHSS. Permanent education in health: a review. Rev Saúde Pública [Internet]. 2014 [cited 2015 June 15];48(1):170-85. Available from: http://www.scielo.br/pdf/rsp/v48n1/en_0034-8910-rsp-48-01-0170.pdf

4. Caveião C, Zagonel IPS, Coelho ICM, Peres AM, Montezeli JH, Venturi KK. Student's competences with regard to nursing administration: an exploratory and descriptive research. Online Braz J Nurs [Internet]. 2014 [cited 2015 June 15];13(4):602-12. Available from: http:// www.objnursing.uff.br/index.php/nursing/article/view/4770/pdf_332

5. Almeida ML, Peres AM. Conhecimentos, habilidades e atitudes sobre a gestão dos formados de enfermagem de uma universidade pública brasileira. Invest Educ Enferm [Internet]. 2012 [citado 2015 jun. 15];30(1):66-76. Disponível em: http://aprendeenlinea.udea.edu.co/ revistas/index.php/iee/article/view/7823/10514

6. Melnyk BM, Gallagher-Ford L, Long LE, Fineout-Overholt E. The establishment of evidence-based practice competencies for practicing registered nurses and advanced practice nurses in real-world clinical settings: proficiencies to improve healthcare quality, reliability, patient outcomes, and costs. Worldviews Evid Based Nurs. 2014;11(1):5-15.

7. Thiollent M. Pesquisa-ação nas organizações. São Paulo: Atlas; 2009.

8. Thiollent M. Metodologia da pesquisa-ação. São Paulo: Cortez; 2011.

9. Peres HHC, Leite MMJ, Gonçalves VLM. Educação continuada: recrutamento e seleção, treinamento e desenvolvimento e avaliação de desempenho profissional. In: Kurcgant P, coordenadora. Gerenciamento em enfermagem. $2^{\text {a }}$ ed. Rio de Janeiro: Guanabara Koogan; 2012. p. 137-53.

10. Bardin L. Análise de conteúdo. Lisboa: Edições 70; 2011.

11. Manenti AS, Ciampone MHT, Mira VL, Minami LF, Soares JM. The construction process of managerial profile competencies for nurse coordinators in the hospital field. Rev Esc Enferm USP [Internet]. 2012 [cited 2013 Oct 20];46(3):722-8. Available from: http://www.scielo. br/pdf/reeusp/v46n3/en_27.pdf

12. Amestoy SC, Backes MS, Triandade LL, Canever BP. The scientific production regarding leadership in the context of nursing. Rev EsC Enferm USP [Internet]. 2012 [cited 2013 Nov 20];46(1):219-24. Available from http://www.scielo.br/pdf/reeusp/v46n1/en_v46n1a30.pdf

13. Ekström L, Idvall E. Being a team leader: newly registered nurses relate their experiences. J Nurs Manag. 2015;23(1):75-86.

14. Ni C, Hua Y, Shao P, Wallen GR, Xu S, LiL. Continuing education among Chinese nurses: a general hospital-based study. Nurse Educ Today. 2014;34(4):592-7.

15. Jesus MCP, Figueiredo MAG, Santos SMR, Amaral AMM, Rocha LO, Thiollent MJM. Permanent education in nursing in a university hospital. Rev Esc Enferm USP [internet]. 2011 [cited 2013 Oct. 21];45(5):1229-36. Available from: http://www.scielo.br/pdf/reeusp/v45n5/ en_v45n5a28.pdf

16. Salum NC, Prado ML. Continuing education in the development of competences in nurses. Texto Contexto Enferm [Internet]. 2014 [cited 2015 June 16];23(2):301-8. Available from: http://www.scielo.br/pdf/tce/v23n2/0104-0707-tce-23-02-00301.pdf

17. Portella Ribeiro J, Pereira Rocha L. Permanent education in health: an instrument to enhance interpersonal relations in nursing work. Invest Educ Enferm. 2012; 30(3):412-7.

18. Meira MDD, Kurcgant P. Political-ethical skill development in nursing undergraduates. Rev Esc Enferm USP [Internet]. 2013 [cited 2014 Oct 10];47(5): 1203-10. Available from: http://www.scielo.br/pdf/reeusp/v47n5/0080-6234-reeusp-47-05-1203.pdf

19. Silva CT, Terra MG, Mostardeiros S, Ribeiro D, Lavich C, Xavier M. Núcleo de educação permanente em enfermagem: perspectiva em um hospital de ensino. Rev Pesq Cuid Fundam J [Internet]. 2013 [citado 2015 jun. 18];5(3):114-21. Disponível em: http://www.seer.unirio.br/ index.php/cuidadofundamental/article/view/2044/pdf_826

20. Leite MMJ, Pereira LL. Educação continuada em enfermagem. In: Kurcgant P, coordenadora. Administração em enfermagem. São Paulo: EPU; 2011. p. 147-63.

21. Costa DB, Vannuchi MTO, Haddad MCFL, Cardoso MGP, Silva LG, Garcia SD. Custo de educação continuada para equipe de enfermagem de um hospital universitário público. Rev Eletr Enf [Internet]. 2012 [citado 2013 out. 10]; 14(2):257-66. Disponível em: http://www.fen. ufg.br/revista/v14/n2/v14n2a05.htm

22. Bezerra ALQ, Queiroz ES, Weber J, Munari DB. O processo de educação continuada na visão de enfermeiros de um hospital universitário. Rev Eletr Enf [Internet]. 2012 [cited 2014 out. 10];14(3):618-25. Disponível em: http://www.revistas.ufg.br/index.php/fen/ article/view/12771/13431 